\title{
What would farmers do? Adaptation intentions under a Corn Belt climate change scenario
}

\author{
Gabrielle E. Roesch-McNally ${ }^{1} \cdot$ J. Gordon Arbuckle $^{2} \cdot$ John Charles Tyndall $^{3}$
}

Accepted: 22 June 2016/Published online: 11 August 2016

(C) The Author(s) 2016. This article is published with open access at Springerlink.com

\begin{abstract}
This paper examines farmer intentions to adapt to global climate change by analyzing responses to a climate change scenario presented in a survey given to largescale farmers $(\mathrm{n}=4778)$ across the US Corn Belt in 2012. Adaptive strategies are evaluated in the context of decision making and farmers' intention to increase their use of three production practices promoted across the Corn Belt: no-till farming, cover crops, and tile drainage. This paper also provides a novel conceptual framework that bridges a typology of adaptation with concepts that help predict intentionality in behavior change models. This conceptual framework was developed to facilitate examination of adaptive decision making in the context of agriculture. This research effort examines key factors that influence farmers' intentions to increase their use of the practices evaluated given a climate change scenario. Twenty-two covariates are examined across three models developed for no-till farming, cover crops, and tile drainage. Findings highlight that farmers who believed they should adjust their practices to protect their farm from the negative impacts of increased weather variability were more likely to indicate that they
\end{abstract}

Gabrielle E. Roesch-McNally

groeschmcnally@fs.fed.us

J. Gordon Arbuckle

Arbuckle@iastate.edu

John Charles Tyndall

jtyndall@iastate.edu

1 Climate Hub Fellow, USDA Climate Hubs, 3200 SW Jefferson Way, Corvallis, OR 97331, USA

2 Department of Sociology, Iowa State University, 303c East Hall, Ames, IA 50011, USA

3 Department of Natural Resource Ecology and Management, Iowa State University, 238 Science II, Ames, IA 50011, USA would increase their use of each of the practices in response to climate change. Additionally, visiting with other farmers to observe their practices was positively associated with farmers' intentions to increase their use of the adaptive strategies examined. Farmers who were currently using no-till farming, cover crops, and tile drainage were also more likely to plan to increase their use of these practices in response to increased weather variability associated with climate change. However, farmers who reported high levels of confidence in their current practices were less likely to plan on changing their use of these practices in response to climatic changes.

Keywords Agriculture - Adaptation - Climate change . Farmer decision making $\cdot$ Resilience

\section{Introduction}

Agricultural production in the US Corn Belt accounts for the majority of the corn (Zea mays L.) and soybean (Glycine max L.) produced in the United States (USDA-FAS 2015). Further, this region is responsible for over a third of the global supply of corn and is the world's largest producer and exporter of soybeans (USDA-FAS 2015). While this commodity-driven system is very productive and yield per hectare has increased over the last half-century (Fuglie et al. 2007), global climate change is projected to drive greater weather variability and is expected to have a largely negative impact on crop yields in the region (Melillo et al. 2014). Yield decreases are expected due to increases in the severity and frequency of extreme weather events and associated outcomes such as increased disease and pest pressure (Chhetri et al. 2014; Hatfield et al. 2014; Melillo et al. 2014). Overall, climate change related weather 
impacts are expected to hinder regional production goals not only through reduced yields (Hatfield et al. 2014) but also by exacerbating negative environmental impacts of production, such as increased pollution from sediment loading and nutrient transport (Reilly et al. 2003; Donner and Kucharik 2008; Broussard and Turner 2009; Jordan and Warner 2010; Broussard et al. 2012).

To reduce the risks related to current and predicted changes in the Corn Belt, it is widely recognized that farmers throughout the region will need to adapt their farm systems to the effects of climate change to build greater resilience (Howden et al. 2007; Arbuckle et al. 2013a). As such, vulnerability and resilience are linked concepts; vulnerability refers to a system's exposure to adverse impacts and its capacity to cope and adapt (IPCC 2014), whereas resilience is defined as a system's ability to respond and change "in ways that maintain their essential function, identity and structure while also maintaining the capacity for adaptation, learning, and transformation" (IPCC 2014, p. 5), which "may or may not succeed in moderating harm or exploring potential benefits" (Moser and Ekstrom 2010, p. 22026). Farmer adaptive decision making within the context of their farm business takes place on both short-term and long-term time frames and is in response to both climatic and non-climatic stimuli and the broader social, political, and economic system(s) that they operate within (Smit and Skinner 2002). Adaptation in this context is characterized by individual farmers attempting to manage agronomic conditions in their fields to minimize production and environmental risk; particularly, in response to a changing climate regime.

Given the importance of farmer decision making, it is essential to understand how farmers might change their production practices in response to a changing climate. Yet there is very little research that examines how farmers might respond to climate change stressors (Howden et al. 2007; Rejesus 2013). This study sought to answer the research question: how will climate change and associated weather variability influence farmer adoption and increased use of key conservation and production practices? Our study examined farmer responses to a survey question that presented a realistic climate change scenario to nearly 5000 large-scale corn farmers in the US Corn Belt. These farmers assessed their intended use of specific practices that can serve to meet both production and conservation goals. For this analysis, we focus on three key practices: no-till farming, ${ }^{1}$ cover crops $^{2}{ }^{2}$ and subsurface tile

\footnotetext{
1 The practice of no-till farming requires that farmers plant crops directly into the previous season's crop residue with minimal disturbance to the soil.

${ }^{2}$ Cover crops are plants grown in-between plantings of cash crops during fallow periods (e.g., cereal rye, Secale cereale planted during the winter).
}

drainage. $^{3}$ No-till farming and cover crops have the potential to improve water quality and prevent erosion by mitigating nutrient leaching and reducing wind and water erosion (ISUEO 2014), while subsurface tile is an effective way to drain excess water and boost productivity in certain soil types (Oquist et al. 2007). In 2012 it was estimated that only $30 \%$ of cropland in the region was in no-till farming and just $3 \%$ in cover crops (NASS 2014b); therefore the use of no-till farming and cover crops could be expanded across cropland in the Corn Belt. In certain locations across the Corn Belt, tile drainage is installed on most of the land that is suitable for the practice (e.g., Iowa and Illinois); however there are regions in the Corn Belt where additional tile drainage or improvements to drainage water management systems could provide crop yield benefits, and therefore, intensification and expansion of tiling is expected across the region (Sugg 2007).

The following section outlines the conceptual framework that we developed to describe and explain agricultural adaptation by integrating an adaptation typology with behavioral theories that examine intentions to change behavior. The survey data collection and analysis section describes the data and analytical procedures used to analyze survey data. The results section examines the findings from three separate models that explore intentions to increase the use of no-till farming, cover crops, and subsurface tile drainage in addition to comparisons made across all models. The discussion section connects the results to the conceptual framework developed as part of this study. Finally, we provide a brief conclusion with outreach, research, and policy recommendations.

\section{Conceptual framework for agricultural adaptation}

We developed a conceptual model (Fig. 1) that facilitates the understanding of farmer adaptive decision making. This framework links a typology of adaptation developed to explain adaptive decision making (Smit et al. 2000), particularly in the context of agriculture (Smit and Skinner 2002), with a theoretical framework for examining behavioral intentions grounded in the Theory of Planned Behavior (TPB) (Ajzen 1991) and the Reasoned Action Approach (RAA) (Fishbein and Ajzen 2010). By linking these two conceptual frameworks we are better able to understand intention to adapt to climate change in the agricultural context.

\footnotetext{
${ }^{3}$ Subsurface tile drainage is "a conduit, such as corrugated plastic tubing, tile, or pipe, installed beneath the ground surface to collect and/or convey drainage water" (Schnepf and Cox 2006, p. 107). Tile drainage historically meant installation of clay pipe-like structures used to drain excess soil moisture but these have largely been replaced by corrugated plastic tubing.
} 


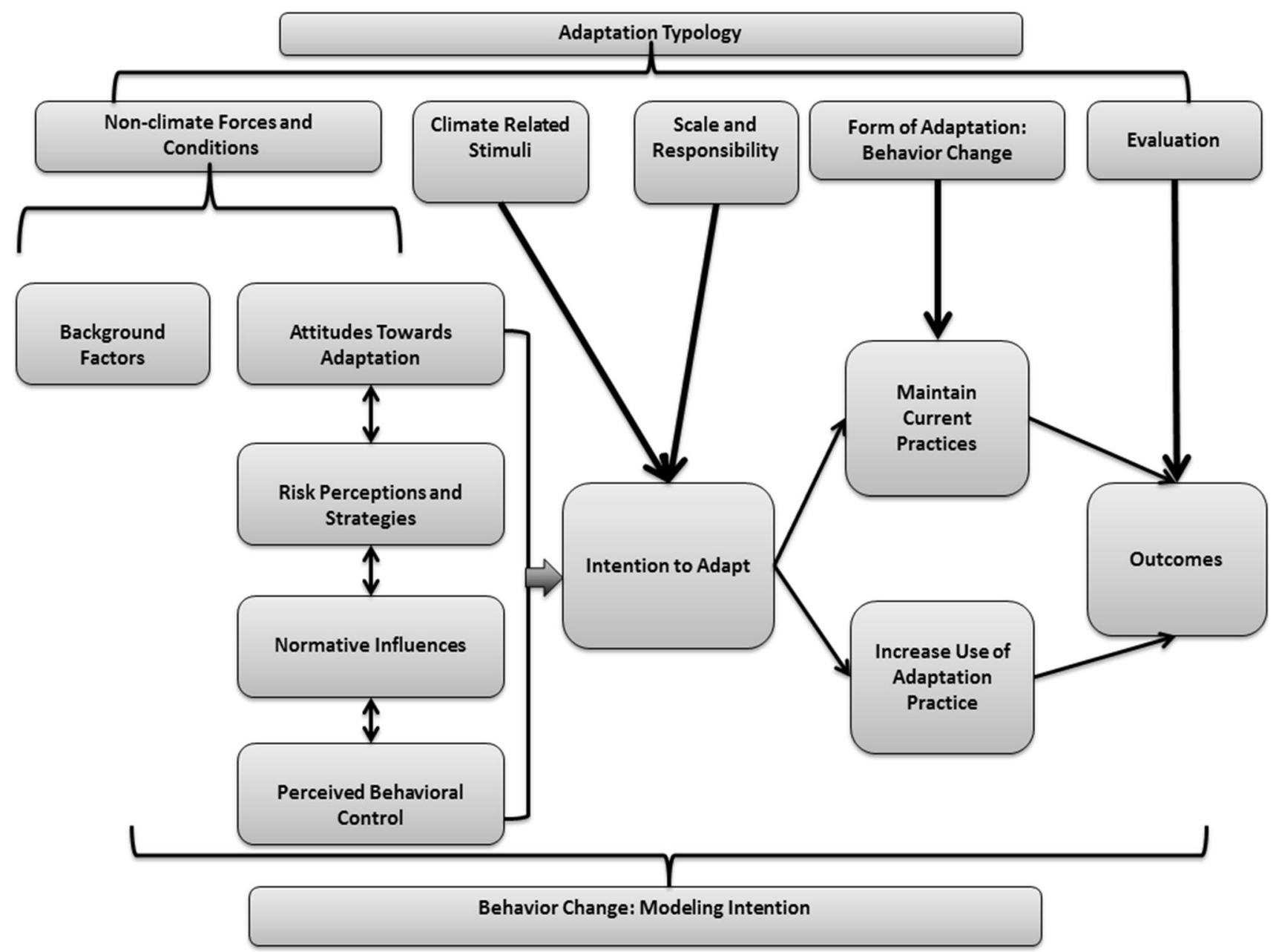

Fig. 1 This conceptual framework combines the "anatomy of adaptation" typology outlined in by Smit et al. (2000) with a modified framework drawing from the theory of planned behavior (Ajzen 1991) and the reasoned action approach (Fishbein and Ajzen 2010)

Smit et al. (2000) identify key factors that help to explain decisions regarding managing weather/climate risk, which include climate related stimuli, aspects of scale and responsibility, the form of adaptation, non-climatic factors/conditions, and finally evaluation of adaptation effects. The concept of climate-related stimuli refers to the form, timing, and severity of a given climate signal (Smit et al. 2000). Scale and responsibility refer to whom or what entity is adapting and at what scale, including the intent and purposefulness of the adaptation (autonomous or planned) as well as the timing and duration (anticipatory, concurrent, or reactive) (Smit and Skinner 2002). Our research focused on how farmers intend to change or maintain current management practices in response to changes in the climate signal, and the form of adaptive actions. Smit and Skinner (2002) identify four major forms of adaptation in the agricultural sector: technical development, government/insurance, farm production practices, and farm financial management. Our research rests primarily on farm production and conservation practices (i.e., no-till farming, cover crops, and tile drainage) as the form of adaptation.

Smit et al. (2000) identify the importance of non-climatic forces and conditions in adaptation decision making. Indeed, many of the decisions farmers make are in response to non-climatic factors, which include factors associated with the broader ecological and socioeconomic context of agricultural production (Blesh and Wolf 2014). Multiple theories help explain the role of intention and how this influences changes in behavior, including two prominent theories outlined in the TPB (Ajzen 1991) and the RAA (Fishbein and Ajzen 2010). Such models have been used to explain agricultural and conservation decision making (e.g., Reimer et al. 2012a; Arbuckle and Roesch-McNally 2015). In Fig. 1 we represent these concepts as attitudes towards adaptation, risk perception and strategies, normative influences, perceived behavioral control, and background factors.

The first category of non-climatic forces and conditions included in our conceptual model is attitudes towards 
adaptation. Attitudes are multidimensional and have been found to be important predictors of behavioral intentions, including intentions related to conservation practice adoption (Prokopy et al. 2008; Baumgart-Getz et al. 2012; Reimer et al. 2012b). Ajzen notes that attitudes should be measured directly in reference to a specific behavior and are defined as the "degree to which a person has favorable or unfavorable evaluation or appraisal of the behavior in question" (1991, p. 10). Additionally, there is evidence that farmers' beliefs (described as necessary precursors to attitudes by Fishbein and Ajzen 2010) about the potential severity of climate impacts and causes of climate change can influence their support for adaptive and/or mitigative actions (Howden et al. 2007; Arbuckle et al. 2013b; Hyland et al. 2015).

The second category for non-climatic forces and conditions is risk perceptions and strategies. In general, farmer perceptions of the potential risks associated with increased weather variability due to climate change have been shown to influence their support for adaptation (Arbuckle et al. 2013b). Actual physical vulnerability associated with experiences of extreme weather has been shown to increase the perception of risks associated with climate change (Brody et al. 2008) in addition to other political and social values (Cutler 2015). Environmental risks have also helped to explain the adoption of cover crops, no-till, and increased use of tile drainage in the US Midwest (e.g., Morton et al. 2015). Generally, perceived risks have a strong and positive relationship with support for public responses and individual behavioral intentions to address climate change impacts (O'Connor et al. 1999; Zahran et al. 2006; Arbuckle et al. 2013b; Hyland et al. 2015). Farmers also employ a number of risk management strategies to mitigate both weather-related and financial risks associated with their agricultural production systems. Rejesus (2013) found that farmers are likely to employ a diverse set of risk management strategies to deal with extreme weather, which can include diversifying crops, use of crop insurance, modifying lease arrangements, and retiring from farming. Specifically, crop insurance is a key risk management tool currently used by many farmers across the Corn Belt, particularly as a way to protect their farm operations from catastrophic crop losses caused by extreme weather events (NASS 2014a). Additionally, greater diversification of cropping systems can help explain farmer adoption of conservation practices (Saltiel et al. 1994; Singer et al. 2007; Arbuckle and Roesch-McNally 2015) and is also considered an important strategy for building greater resiliency in response to more extreme weather (Jordan and Warner 2010; Lin 2011).

The third category examined in our conceptual framework is the concept of normative influences. Specifically, decision making is considered a social process, influenced by community norms, whereby individuals enlist others, often those in their social network, to help them make specific management decisions (Pannell et al. 2006). Social networks are important predictors of farmer transitions to sustainable agricultural and conservation-oriented practices (Coughenour 2003; Carolan 2006; Atwell et al. 2009; Blesh and Wolf 2014; Nelson et al. 2014). Additionally, norms also influence what constitutes a "good farmer," which is a social construct laden with values and aesthetic preferences (e.g., "a freshly tilled field is beautiful") (Burton 2004). Ideas about what constitutes a good farmer can have a normative influence on farmers and in some cases can actuate key conservationist identities (Schneider et al. 2010; McGuire et al. 2013), which can impact a farmer's decision to use or increase their use of certain conservation practices (Arbuckle 2013; Hyland et al. 2015).

The fourth category that is included in our conceptual framework is the notion of perceived behavioral control. Studies on environmental decision making have illustrated that perceived behavioral control (PBC), or the confidence that an individual has in their ability to perform certain activities or achieve certain outcomes (Ajzen 1991), has a positive influence on behavioral intentions (Schwartz and Howard 1981; Ajzen 1991). PBC has also been found to influence decision making specifically in regards to agricultural management practices (Reimer et al. 2012a). A high level of perceived behavioral control has also been found to be negatively associated with farmers' concern about and support for adaptive actions in light of climate change (Arbuckle et al. 2014).

Finally, the category of background factors includes a number of farmer and farm characteristics that have been used to explain conservation practice adoption. Factors that have been found to be more or less consistently influential include education, age, income, farm size, and off-farm income (Soule et al. 2000; Pannell et al. 2006; Knowler and Bradshaw 2007; Prokopy et al. 2008; Baumgart-Getz et al. 2012). However, the sign and effect of each of these characteristics are not always consistent, which may have to do with variation in the types of practices analyzed and the confluence of other factors discussed above. Additionally, habits, or behaviors practiced regularly, improves the fit of behavioral change models (Klöckner 2013) and past/current practices can be an important variable for understanding adoption of agricultural conservation practices in particular (Wilson et al. 2014).

Smit et al. (2000) included the evaluation concept in their typology of adaptation in order to highlight the importance of measuring outcomes associated with adaptive actions, which can enable an assessment of whether adaptive actions reduce or increase vulnerability. Evaluating the spatial and temporal impacts of adaptation decision 
making is a complex process because adaptation decisions are made by individual actors who may experience benefits and/or losses as a consequence of their decisions while these same decisions, in aggregate, may lead to different, and potentially negative, effects at the landscape or watershed scale. Farmers are likely to evaluate the outcomes of their action at the field and farm scale (e.g., improved drainage due to installation of tile drains). However, this evaluation is distinct from a more landscapescale evaluation of the impacts of multiple actions taken by farmers and their aggregate impacts at spatial and temporal scales.

\section{Data collection and analysis}

\section{Survey data}

Survey data were collected through a stratified random sample of Corn Belt farmers across 22 six-digit Hydrologic Code Unit (HUC6) watersheds that cover a large proportion of 11 contiguous Corn Belt states (see Arbuckle et al. 2013a). The sample frame consisted of 103,126 largerscale corn producers, defined as farm operations that manage more than 32 ha of corn and generate a minimum of US\$100,000 of gross sales. Across the 11 states sampled, these farms represented $78 \%$ of the total cropland hectares farmed and $27 \%$ of total farms with cropland (NASS 2009).

The survey was mailed in February 2012 to 18,707 farmers using a three-wave mailing process where the survey was mailed, then a reminder postcard was sent, followed by a final survey sent to non-responders (Arbuckle et al. 2013a). A sample size of 4778 was achieved with an effective response rate of $26 \%$. Comparisons of respondents to non-respondents based on a range of farmer and farm attributes (e.g., age, farm size, hectares in different crops, number of livestock) indicated no meaningful differences between respondents and non-respondents, providing no evidence of a non-response bias and indicating that our sample is representative of the eligible population of larger-scale farmers in the Corn Belt region (Arbuckle et al. 2013a). Sampling weights were developed to account for differences in response probability at the watershed level and were applied to the entire dataset before statistical analyses were performed (see Loy et al. 2013).

\section{Climate change scenario}

The specific question used for this analysis asked how farmers might change their practices given a climate change scenario. Respondents were asked to consider this text: "Suppose the following scenario were to happen in the near future: Violent storms/extreme rain events will become more frequent, particularly in the spring; more extreme rain events will increase likelihood of flooding and saturated soils; Periods between rains will be longer, increasing likelihood of drought; and Changes in weather patterns will increase crop insect, weed and disease problems." This scenario was followed up with the question: "If you knew with certainty that these conditions would occur, would the following practices on the cropland you own and rent increase, or stay the same?" Farmers were then provided with a list of practices that are considered to be potentially effective adaptation actions; however, the focus of this paper is focused on only three of these practices, including no-till farming, cover crops, and tile drainage.

\section{Analytical approach}

We use a binary logistic regression to analyze farmers' stated intent regarding the use of no-till farming (Model 1), cover crops (Model 2) and tile drainage (Model 3) on land that they own (Table 1), in response to the climate change scenario. Logistic regression is an appropriate statistical method to use when exploring models with binary dependent variables (see Arbuckle and Roesch-McNally 2015).

\section{Independent variables}

The conceptual framework outlined in Fig. 1 was employed to guide the selection of variables included in each of the three models that were assessed. Twenty-two covariates (see Table 2) were included in the three models examined. These covariates are organized by conceptual category, in alignment with Fig. 1, which characterize nonclimate forces and conditions relevant to farmer adaptation. These data conform to the assumptions of logistic regression with the exception of two variables, measuring hectares in crop insurance and gross farm revenue, which were transformed using the natural $\log$ in order to correct problems with right skewed non-normal data.

Three variables were included that measure attitudes towards adaptation and one variable to measure climate change beliefs (Table 2). These include variables measuring farmers' attitudes toward taking additional steps to protect their farmland from increased weather variability (I Adapt), beliefs about whether it is important that farmers, in general, adapt to climate change to ensure long-term success of US agriculture (Farmers Adapt), and belief that that there is too much uncertainty about climate change to justify adaptive action (Uncert NoAdapt). A fourth variable was included to measure farmer beliefs that their operation will be harmed by climate change ( $\mathrm{CC}$ harm). 
Table 1 Descriptive statistics for the three models examined as part of this study

\begin{tabular}{|c|c|c|c|c|c|}
\hline Model & Variable & Question & $\mathrm{N}$ & Mean & SD \\
\hline 1 & $\operatorname{ming}$ & ncrease, & 3281 & 0.34 & 0.47 \\
\hline Iodel 2 & Cover crop & Would use of this practice stay the same or increase, given the climate change scenario? & 2704 & 0.36 & 0.4 \\
\hline Model 3 & Tile drainage & Would use of this practice stay the same or increase, given the climate change scenario? & 3374 & 0.57 & 0.49 \\
\hline
\end{tabular}

Each variable was measured as a binary response ( $O$ stay the same, $l$ increase)

We include six variables that measure risk perceptions and management strategies (Table 2). Four variables were included that measure the degree of concern that farmers have regarding potential negative weather-related outcomes: increased flooding (Flooding), longer periods of drought (Droughts), more frequent extreme rains (Extreme Rains), and soil erosion (Erosion). We also include two variables that measure risk management strategies that farmers employ, including a variable on whether farmers are diversifying into other forms of production/different crops as a way to manage weather related risks (Diversification) and a variable that measures how many hectares a farmer has insured through federal crop insurance (Crop Insurance).

Three variables are included in our models that measure normative influences (Table 2). Two variables measure the latent construct of a conservationist identity (Stewardship) and a more production-oriented identity (Productivist). Farmers were asked to rate a suite of survey items meant to describe what attributes constitute a "good farmer" (Burton 2004). Responses to these questions were used to construct the Stewardship and Productivist variables by using a confirmatory factor analysis (see "Appendix"). We also include a variable that measures the importance of visiting with other farmers (Visit Farmers) as another normative influence on farmer intentions.

Two variables are used to measure the concept of Perceived Behavioral Control (PBC). The first variable measures how confident farmers are that their current practices will be able to effectively mitigate the impacts associated with increasing weather variability (Confidence in Practices). The second variable assesses how confident farmers are in their knowledge and skills to deal with weatherrelated threats to their farm (Knowledge and Skills).

Finally, seven variables were included in the model that measure key characteristics (e.g., background factors) at the farmer and farm-level. These included age (Age), highest level of education (Education), the value of farm sales (Farm Revenue) and finally, the percent of highly erodible land that was planted to crops in 2011 (Erodible Land). Three variables measure farmers' current use of the practices examined, including their use of no-till farming (No-till), cover crops (Cover Crops), and tile drainage (Tile Drainage).

\section{Results}

\section{Management practice and intention}

This analysis focuses on predicting adaptive responses to climate change, measured as farmers' stated intentions to increase use of selected production and conservation practices. In all the models, independent variables measuring whether farmers are currently using the practices are included as it is expected that current practices will have an influence on what farmers would do in response to climate change. It is useful, however, to understand what "increase" in practice usage means in the context of our analysis. For no-till farming, $66 \%$ of farmers indicated that they would maintain their current management practices (see Table 3). Among the $34 \%$ who indicated that they would increase their use of no-till farming only $8 \%$ would adopt the practice anew. Thirty-six percent of farmers indicted that they would increase use of cover crops, most of whom would be adopting the practice for the first time. Finally, for tile drainage, very few farmers who did not already use the practice indicated that they would adopt the practice, but $53 \%$ of those who currently have drainage would intensify or expand tile coverage in response to increased weather variability associated with climate change. Note, however, that the focus of the analysis is on intended action, moving from the status quo (stay the same) to increased use.

\section{Model one: increasing the utilization of no-till farming}

Three of the variables from the attitudes towards adaptation category were statistically significant predictors in the notill farming model (Table 4). The variable measuring whether farmers believe that they should personally take action to protect their land from increased weather variability, $I$ Adapt, had a highly significant $(p<0.001)$ and positive relationship with intentions to increase no-till farming. The variable measuring uncertainty (Uncert NoAdapt) $(p<0.05)$ had the opposite effect, such that farmers who believe there is too much uncertainty about climate change to justify changing their practices were less likely to 
Table 2 A total of 22 covariates were included in the models

\begin{tabular}{|c|c|c|c|c|c|}
\hline Variable category & Variable & Question/statement & Measure & Mean & SD \\
\hline \multirow[t]{4}{*}{$\begin{array}{l}\text { Attitudes towards } \\
\text { adaptation }\end{array}$} & I Adapt & $\begin{array}{l}\text { I should take additional steps to protect } \\
\text { the land I farm from increased } \\
\text { weather variability }\end{array}$ & Five-point agreement scale & 3.47 & 0.80 \\
\hline & Farmers adapt & $\begin{array}{l}\text { It is important for farmers to adapt to } \\
\text { climate change to ensure the long- } \\
\text { term success of US agriculture }\end{array}$ & Five-point agreement scale & 3.56 & 0.86 \\
\hline & $\begin{array}{l}\text { Uncert } \\
\text { NoAdapt }\end{array}$ & $\begin{array}{l}\text { Too much uncertainty about the } \\
\text { impacts of climate change to justify } \\
\text { changing my agricultural practices } \\
\text { and strategies }\end{array}$ & Five-point agreement scale & 3.67 & 0.93 \\
\hline & $\mathrm{CC}$ harm & $\begin{array}{l}\text { My farm operation will likely be } \\
\text { harmed by climate change }\end{array}$ & Five-point agreement scale & 2.98 & 0.78 \\
\hline \multirow{6}{*}{$\begin{array}{l}\text { Risk perceptions and } \\
\text { strategies }\end{array}$} & Flooding & Concern about increased flooding & Four point scale & 1.92 & 0.84 \\
\hline & Droughts & $\begin{array}{l}\text { Concern about longer dry periods and } \\
\text { drought }\end{array}$ & Four point scale & 2.67 & 0.87 \\
\hline & Extreme rains & $\begin{array}{l}\text { Concern about more frequent extreme } \\
\text { rains }\end{array}$ & Four point scale & 2.48 & 0.90 \\
\hline & Erosion & Concern about increased soil erosion & Four point scale & 2.26 & 0.80 \\
\hline & Diversification & $\begin{array}{l}\text { Diversifying into other forms of } \\
\text { production/different crops as a way } \\
\text { to manage weather related risks }\end{array}$ & Binary response $($ no $=0$, yes $=1)$ & 0.10 & 0.30 \\
\hline & Crop insurance & Crop insurance hectares & Continuous & 238 & 282 \\
\hline \multirow[t]{3}{*}{ Normative influences } & Productivist & $\begin{array}{l}\text { Confirmatory factor score (see } \\
\text { "Appendix") }\end{array}$ & Continuous & 0.00 & 0.51 \\
\hline & Stewardship & $\begin{array}{l}\text { Confirmatory factor score (see } \\
\text { "Appendix") }\end{array}$ & Continuous & 0.00 & 0.69 \\
\hline & Visit farmers & $\begin{array}{l}\text { It is important for me to visit other } \\
\text { farms to look at their practices and } \\
\text { strategies }\end{array}$ & Five-point agreement scale & 3.32 & 0.88 \\
\hline \multirow[t]{2}{*}{$\begin{array}{l}\text { Perceived behavioral } \\
\text { control }\end{array}$} & $\begin{array}{l}\text { Knowledge and } \\
\text { skills }\end{array}$ & $\begin{array}{l}\text { I have the knowledge and skills to deal } \\
\text { with any weather-related threats to } \\
\text { the viability of my farm operation }\end{array}$ & Five-point agreement scale & 3.35 & \\
\hline & $\begin{array}{l}\text { Confidence in } \\
\text { practices }\end{array}$ & $\begin{array}{l}\text { How confident are you in your current } \\
\text { practices given a climate change } \\
\text { scenario? }\end{array}$ & Five-point agreement scale & 2.86 & 0.73 \\
\hline \multirow[t]{7}{*}{ Background factors } & Age & Age & Continuous & 55.94 & 11.01 \\
\hline & Education & Highest level of education & $\begin{array}{l}\text { Ordinal scale }(1=\text { some formal ed., } \\
6=\text { grad. school })\end{array}$ & 3.24 & 1.33 \\
\hline & Farm revenue & Farm revenue from sales & Continuous & 463,412 & 674,736 \\
\hline & Erodible land & $\begin{array}{l}\text { Percentage of highly erodible farmed } \\
\text { land in } 2011 \text { that was planted to } \\
\text { crops }\end{array}$ & Continuous & 22.52 & 39.04 \\
\hline & No-till & Currently uses no-till & Binary response $($ no $=0$, yes $=1)$ & 0.60 & 0.49 \\
\hline & Cover crops & Currently uses cover crops & Binary response $($ no $=0$, yes $=1)$ & 0.22 & 0.42 \\
\hline & Tile drainage & $\begin{array}{l}\text { Currently has land that is artificially } \\
\text { drained through tile or other methods }\end{array}$ & Binary response $($ no $=0$, yes $=1)$ & 0.77 & 0.42 \\
\hline
\end{tabular}

Descriptive statistics are presented (mean, and SD). The name of the variable, the associated question/statement from the survey and the scale that the variable is measured on are also presented

increase their use of no-till farming. The CC Harm variable, or those farmers who believe that their farm will be negatively impacted by climate change, had a positive relationship $(p<0.05)$ with increasing the use of no-till farming.
One variable measuring risk perceptions and strategies and another variable assessing normative influences were statistically significant predictors of No-till farming adaptation intentions. The variable measuring concern about 
Table 3 Percentage of farmers surveyed who plan on staying the same or increasing their use of each practice based on whether they currently use the practice or whether they plan to adopt the practice for the first time

\begin{tabular}{lllc}
\hline Stay the same & Percent & Increase & Percent \\
\hline No-till farming & & & \\
Would not increase & 22 & Would adopt & 8 \\
Currently use & 44 & Would increase use & 26 \\
Total & 66 & Total & 34 \\
Cover crops & & & \\
Would not increase & 48 & Would adopt & 23 \\
Currently use & 16 & Would increase use & 14 \\
Total & 64 & Total & 36 \\
Tile drainage & & & \\
Would not increase & 12 & Would adopt & 4 \\
Currently use & 31 & Would increase use & 53 \\
Total & 43 & Total & 57 \\
\hline
\end{tabular}

increased erosion (Erosion) had a highly significant $(p<0.001)$ and positive relationship with the intention of increasing the use of no-till farming. The normative influence of visiting other farmers (Visit Farmers) also had a positive and significant effect $(p<0.05)$.

One variable measuring perceived behavioral control and one variable measuring background factors were also significant predictors of adaptation intentions regarding notill farming. Confidence in Practices had a highly significant $(p<0.001)$ and negative relationship with intentions to increase the use of no-till farming. The current use of notill farming (No-till) had a positive and significant $(p<0.05)$ relationship with improving the odds that a farmer would increase their use of no-till farming in response to greater weather variability due to climate change.

\section{Model two: increasing the use of cover crops}

One of the variables measuring attitudes towards adaptation and two variables assessing risk perceptions and strategies were significant in predicting adaptation intentions in the cover crops model (Table 4). The variable measuring support for taking individual adaptive actions ( $I$ Adapt $)$ was highly significant $(p<0.001)$ with a positive relationship with intention to increase use of cover crops. The variables measuring concern about increased risks associated with Extreme Rains $(p<0.05)$ and increased Erosion $(p<0.001)$ both had a positive relationship with intentions to increase the use of cover crops.

Two variables measuring normative influences and one variable measuring perceived behavioral control were significant in the cover crops model. A Stewardship identity was highly significant $(p<0.001)$ and positively associated with intentions to increase the use of cover crops. Visit Farmers, or the importance of networks, also had a positive and highly significant $(p<0.001)$ relationship with plans to increase the use of cover crops in response to more extreme weather. However, the variable Confidence in Practices had a negative and significant relationship $(p<0.01)$ with intention to increase the use of cover crops.

Three background factors were significant predictors of intention to use cover crops. Age had a significant $(p<0.01)$ negative relationship and Education had a highly significant $(p<0.001)$ and positive effect on whether a farmer intends to increase their use of cover crops. Finally, the variables measuring farmers' current use of Cover Crops and No-till both had highly significant $(p<0.001)$ and positive relationships with intention to increase the use of cover crops.

\section{Model three: increasing the use of tile drainage}

Two measures for assessing attitudes towards adaptation are positive and significant $(p<0.01)$ in the tile drainage model (Table 4), with the variables I Adapt and Uncert NoAdapt increasing the odds of a farmer increasing or intensifying tile drainage on their farms given the climate change scenario. Additionally, four variables from the risk perceptions and strategies category were significant in the tile drainage model. The variable measuring concerns about Flooding was highly significant $(p<0.001)$ and had a positive relationship with the likelihood of farmers installing more subsurface tile. The Extreme Rains variable was also significant $(p<0.01)$ and positively associated with the likelihood of installing more tile drainage; however, the perception of drought risk (Droughts) $(p<0.01)$ decreases a farmer's intention to install more drainage. An increase in the number of hectares that are insured (Crop Insurance Hectares $)(p<0.05)$ improves the odds that a farmer intends to increase their use of tile drainage.

One variable measuring normative influences and one variable assessing perceived behavioral control were significant $(p<0.01)$ in the tile drainage model. Visit Farmers increases the odds that a farmer will increase their use of tile drainage. The variable Confidence in Practices was negatively associated with intentions to increase the use of tile drainage.

All three variables in the background factors category were highly significant $(p<0.001)$ in the tile drainage model. Age and Farm Revenue both have a positive relationship with intention to install more tile drainage. The current use of Tile Drainage had an expectedly positive relationship with improving a farmers' intention to use more tile drainage, with a very large odds ratio (Exp(B) 4.97) which suggests a very powerful relationship 
Table 4 Twenty-two covariates presented for all three models, no-till farming (Model 1), cover crops (Model 2) and tile-drain (Model 3)

\begin{tabular}{|c|c|c|c|c|c|c|c|}
\hline Variable category & Variables & $\begin{array}{l}\text { No-till farming } \\
\text { (Model 1) }\end{array}$ & $\operatorname{Exp}(B)$ & $\begin{array}{l}\text { Cover crop } \\
\text { (Model 2) }\end{array}$ & $\operatorname{Exp}(B)$ & $\begin{array}{l}\text { Tile drainage } \\
\text { (Model 3) }\end{array}$ & $\operatorname{Exp}(B)$ \\
\hline & Intercept & $-2.39(1.01)^{*}$ & 0.09 & $-3.53(1.15)^{* *}$ & 0.03 & $-5.56(1.02) * * *$ & 0.00 \\
\hline \multirow{4}{*}{$\begin{array}{l}\text { Attitudes towards } \\
\text { adaptation }\end{array}$} & I Adapt & $0.28(0.07)^{* * *}$ & 1.32 & $0.26(0.08)^{* * *}$ & 1.30 & $0.20(0.06)^{* *}$ & 1.23 \\
\hline & Farmers adapt & $0.07(0.06)$ & 1.07 & $-0.10(0.07)$ & 0.90 & $0.11(0.06)$ & 1.11 \\
\hline & Uncert_NoAdapt & $-0.12(0.06)^{*}$ & 0.89 & $-0.06(0.07)$ & 0.94 & $0.18(0.06)^{* *}$ & 1.19 \\
\hline & CC harm & $0.17(0.07)^{*}$ & 1.19 & $0.02(0.08)$ & 1.02 & $0.05(0.06)$ & 1.05 \\
\hline \multirow{6}{*}{$\begin{array}{l}\text { Risk perception and } \\
\text { strategies }\end{array}$} & Flooding & $0.02(0.06)$ & 1.02 & $-0.07(0.06)$ & 0.93 & $0.26(0.06)^{* * *}$ & 1.29 \\
\hline & Droughts & $-0.03(0.06)$ & 0.97 & $-0.07(0.07)$ & 0.93 & $-0.18(0.06)^{* *}$ & 0.84 \\
\hline & Extreme rains & $-0.01(0.06)$ & 0.99 & $0.15(0.07)^{*}$ & 1.17 & $0.17(0.06)^{* *}$ & 1.19 \\
\hline & Erosion & $0.2(0.06)^{* * *}$ & 1.22 & $0.25(0.07)^{* * *}$ & 1.28 & $0.09(0.06)$ & 1.10 \\
\hline & Diversification & $0.2(0.14)$ & 1.24 & $0.22(0.16)$ & 1.24 & $0.09(0.15)$ & 1.10 \\
\hline & Crop insurance hectares & $0.00(0.02)$ & 1.00 & $0.0(0.02)$ & 1.02 & $0.03(0.02)^{*}$ & 1.03 \\
\hline \multirow[t]{3}{*}{ Normative influences } & Productivist & $-0.08(0.1)$ & 0.92 & $-0.21(0.11)$ & 0.81 & $0.10(0.1)$ & 1.10 \\
\hline & Stewardship & $0.11(0.08)$ & 1.12 & $0.29(0.09) * * *$ & 1.48 & $-0.01(0.07)$ & 1.00 \\
\hline & Visit farmers & $0.11(0.06)^{*}$ & 1.11 & $0.23(0.06)^{* * *}$ & 1.26 & $0.14(0.05)^{* *}$ & 1.16 \\
\hline \multirow{2}{*}{$\begin{array}{l}\text { Perceived behavioral } \\
\text { control }\end{array}$} & Knowledge and skills & $0.07(0.06)$ & 1.07 & $0.01(0.07)$ & 1.01 & $0.06(0.06)$ & 1.07 \\
\hline & Confidence in practices & $-0.39(0.07)^{* * *}$ & 0.67 & $-0.33(0.08)^{* *}$ & 0.72 & $-0.20(0.07)^{* *}$ & 0.82 \\
\hline \multirow[t]{9}{*}{ Background factors } & Age & $0(0.00)$ & 1.00 & $-0.01(0.01)^{* *}$ & 0.99 & $-0.02(0.00) * * *$ & 0.98 \\
\hline & Education & $0.05(0.03)$ & 1.05 & $0.13(0.04)^{* * *}$ & 1.14 & $0.05(0.03)$ & 1.06 \\
\hline & Revenue & $0.02(0.07)$ & 1.02 & $0.13(0.07)$ & 1.14 & $0.21(0.06)^{* * *}$ & 1.24 \\
\hline & Erodible land & $0(0.00)$ & 1.00 & $0(0.00)$ & 1.00 & $-0.00(0.00)$ & 1.00 \\
\hline & No-till & $0.28(0.11)^{*}$ & 1.33 & $0.81(0.11)^{* * *}$ & 2.26 & $-0.01(0.10)$ & 0.99 \\
\hline & Cover crops & $0.1(0.11)$ & 1.10 & $0.49(0.11)^{* * *}$ & 1.63 & $-0.04(0.11)$ & 0.96 \\
\hline & Tile drainage & $-0.15(0.11)$ & 0.86 & $-001(0.12)$ & 0.99 & $1.60(0.13) * * *$ & 4.97 \\
\hline & $\begin{array}{l}\text { Hosmer and Lemeshow } \\
\quad(p \text { value })\end{array}$ & $7.47(0.49)$ & & $7.38(0.50)$ & & $2.27(0.97)$ & \\
\hline & Nagelkirke's psuedo- $\mathrm{R}^{2}$ & 0.09 & & 0.19 & & 0.19 & \\
\hline
\end{tabular}

For each variable in every model we include logit coefficients, \pm SE in parentheses and the log odds (Exp(B)). Hosmer and Lemeshow values and Psuedo- $\mathrm{R}^{2}$ are presented for each model

$* p<0.05 ; * * p<0.01 ; * * * p<0.001$

between the current use of tile drainage and intentions to increase or intensify the use of this practice given expected climate changes.

\section{Model comparison}

There are clear commonalities between each of the models examined (Table 4); however, differences exist, suggesting that some factors driving the intention to increase the use of no-till farming, cover crops, and tile drainage, given the climate change scenario, are unique to the practice. The main similarities between all the models include three key findings. First, farmers who had positive attitudes towards adaptation and believe that they should take additional steps to adapt to increased weather variability on their farm ( $I$ Adapt) indicated that they would increase their use of all three practices explored. Conversely, farmers who expressed high levels of perceived behavioral control conveyed through their confidence in current practices (Confidence in Practices) were less likely to increase their use of any of the practices explored. Additionally, the background factor of current practices, measuring current use of No-till, Cover Crops, and Tile Drainage, were significant and positively associated with plans to increase the use of each of these practices in their respective models. In other words, if they were using a given practice, farmers were more likely to report that they would increase their use in response to climate change impacts. Five variables were not significant in any of the models: Farmers Adapt, Diversification, Productivist, Knowledge and Skills, and Erodible Land.

There are also important similarities between significant covariates when comparing each of the models separately. For example, a comparison of the no-till farming model and the cover crops model shows that high risk perceptions for weather-related risks, specifically the variable Erosion, had a positive and significant relationship with intentions to 
increase the use of both no-till farming and cover crops given the climate change scenario. When comparing the no-till farming model with the tile drainage model, we found that the variable measuring farmers' uncertainty regarding climate change (Uncert NoAdapt), as a measure of attitudes towards adaptation, had a negative and significant relationship with intentions to increase the use of no-till farming, yet the converse was true for tile drainage, with a positive and significant relationship. Finally, when comparing the cover crops model with the tile drainage model we found a few commonalities, including concerns about Extreme Rains, as a measure of risk perception, and the importance of visiting other farmers, Visit Farmers, as a normative influence. Both of these variables improve the likelihood that a farmer would increase their use of cover crops and tile drainage. Age, as an important background factor, decreases the likelihood that a farmer will plan on increasing their use of both cover crops and tile drainage.

\section{Discussion}

These findings illustrate that a third to half of all Corn Belt farmers that were surveyed indicated that they would change their practices in response to projected climate changes. Clearly the effects of extreme weather will influence how farmers respond to climate change (Rejesus 2013). However, non-climatic forces and conditions also influence what farmers intend to do in response to a changing climate (Smit and Skinner 2002).

Generally, attitudes towards adaptation mattered. In particular, the variable measuring whether farmers think that they should take additional steps to protect the land that they farm, I Adapt, was critical for explaining intention to increase the use of all three practices. Farmers are adapters; this is what they do in the context of maintaining viable farm systems (OECD 2012; Arbuckle et al. 2013c), and in particular, those who see it as their responsibility to protect their farm from weather related risks were more likely to intend engagement in adaptive strategies. The significance of this variable emphasizes the importance that farmers place on individual responsibility to protect their land from increased weather variability; however, the variable measuring whether, collectively, farmers should take additional steps to protect farmland from increased weather variability, Farmers Adapt, was not significant in any of the models. This highlights that farmers are open to taking personal action to adapt to climate-related risks on their farm. However, there may be difficulty in marrying this individualistic approach with efforts to design purposeful and collaborative adaptation strategies (Howden et al. 2007).

Across all models, at least one variable in the category of risk perceptions and strategies was an important predictor of intentions to increase the use of no-till farming, cover crops, and tile drainage. In particular, concerns about excess water or risk of soil erosion were significant in all three models. The perception of weather-related risks has been found to be a critical driver in motivating farmers to shift their production and conservation practices, particularly in relation to climate change adaptation (Arbuckle et al. 2013c; Hyland et al. 2015). Our findings suggest that there is a relationship between positive attitudes towards adaptation and higher levels of perceived risks associated with extreme weather, which is similarly found in previous literature (Brody et al. 2008; Arbuckle et al. 2013a).

Farmers who had higher levels of confidence that their current agricultural practices and strategies were sufficient to reduce weather related risks were less likely to indicate that they would increase their use of any of the practices explored. These findings are important to note as other research has suggested that $\mathrm{PBC}$ has a direct impact on intention to change behaviors (Klöckner 2013) and therefore suggests that greater confidence in current practices may discourage adaptive actions. Farmers who reported a high level of confidence in their current practices were distinct from farmers who had a higher perception of weather-related risks because these farmers who had higher perceptions of risk were more likely to increase their use of the practices of interest given projected climate changes. Farmers manage risks through a range of management decisions (Rejesus 2013), not all of them examined here, so there may be factors that are driving confidence that we do not adequately capture (e.g., connectivity to markets, low debt-to-asset ratio). High levels of confidence may present a barrier to making necessary farm-scale changes in response to more extreme and variable weather (Arbuckle et al. 2014); at least to the degree that it inhibits the use of critical adaptive strategies.

The degree of importance respondents placed on visiting other farmers to observe their practices was a significant factor influencing intentions to increase the use of no-till farming, cover crops, and tile drainage. Visiting other farmers to observe what practices they use on their farms has been found to be important in the adoption of a number of farm production practices (Rogers 1995; Coughenour and Chamala 2000; Coughenour 2003; Pannell et al. 2006; Reimer et al. 2012a) and can facilitate important social learning necessary for adopting conservation practices (Pannell et al. 2006; Blesh and Wolf 2014). These findings suggest that building adaptive capacity among farmers will be effectively facilitated, in part, through building more networks among farmers so that they can observe particular practices of interest before experimenting or implementing on their own farms.

Finally, farmers' current use of no-till farming, cover crops, and tile drainage was a strong predictor of stated 
intentions to increase the use of each of the adaptive strategies examined in this study. In other words, the findings suggest that farmers who were more familiar with these practices were more likely to believe that increased use would be an appropriate adaptive response in the context of a changing climate. Given that the three practices are effective adaptive management practices (Morton et al. 2015) this suggests that perhaps greater emphasis on current adoption of these practices could have a positive impact on future adaptation. However, the impacts associated with these practices and the subsequent evaluation of those impacts will depend on the spatial and temporal context in which the evaluation occurs.

\section{Evaluating adaptive strategies}

Our results indicate that many Corn Belt farmers will increase their use of three common adaptation practices in response to predicted climate changes in the region. Increased adoption of these practices would likely lead to more resilient farm-level crop productivity over time. However, it is important to note that each of the practices, individually and in combination, present some risks of negative impacts, at both the field and landscape-scale. For example, researchers should be cognizant that while the practices discussed in this paper are promoted/adopted for their beneficial properties, each of these practices may have associated maladaptive properties, which could ultimately reduce the "effectiveness of purposeful adaptation action and policies across sectors" and challenge achievement of "effective adaptation in practice" (Adger et al. 2005, p. 97). Maladaptation can be defined as "actions taken to avoid or reduce vulnerability to climate change that impacts adversely on, or increases vulnerability of other systems" (Barnett and O'Neill 2010, p. 211). For example, no-till farming and cover crops have been shown to be helpful in reducing some of the negative externalities associated with corn and soybean production. However, use of some cover crops requires chemical burn down, which could lead to greater use of pesticides in the long run (Hoorman 2009) and no-till has been shown, in some cases, to increase nitrogen leaching (Constantin et al. 2010). Tile drainage is considered a standard practice in corn and soybean producing regions of the Corn Belt, however, tile drainage can also have maladaptive properties, contributing to high nitrate concentrations in the Mississippi River and concomitant issues with hypoxia (Goolsby et al. 1999; Oquist et al. 2007), which may be further exacerbated due to more extreme storm events associated with climate change.

The potential impacts of these adaptive strategies illustrate a situation where farm-level resilience may be contrary to resilience at the landscape-scale, in that increased use of a particular practice leads to reduced vulnerability at the field and farm-level but actually leads to greater vulnerability in the larger agroecosystem. Indeed, beneficial adaptations at the individual level may lead to negative consequences that hinder others' ability to adapt (Adger et al. 2005; Nelson et al. 2007). Overall, these instances suggest that there are potential maladaptive properties associated with the practices examined in this study and future research should examine the potential positive and negative impacts associated with these adaptive strategies at both the field and landscape scale.

\section{Broader implications}

There is clear evidence that the Corn Belt is already experiencing more weather variability (Arritt 2016), which suggests that those involved in agricultural research and outreach must encourage farmers to implement adaptive actions on their farms. The findings from this study highlight the opportunity to engage with farmers who are generally confident in their ability to adapt and are willing to take steps to respond to more extreme weather, particularly through efforts that appeal to "farmers' confidence and their capacity to adapt" (Morton et al. 2016, p. 7). Given that farmers' current use of specific conservation practices help to predict what they intend to do in response to a changing climate, it will be important to actively engage farmers in efforts to expand the use and adoption of appropriate soil and water conservation practices now in anticipation of more variable and extreme weather events. Study findings also highlight the importance of farmer networks in expanding the use and adoption of adaptive strategies, suggesting that development of robust farmer networks that allow farmers to observe and experiment with practices will be important for climate change adaptation. This builds on existing knowledge that has highlighted the importance of farmer networks, which have been critical in the adoption soil and water conservation practices in the farming community (Pannell et al. 2006).

\section{Conclusion}

Findings from this study, which examines data from a climate change-focused farmer survey of unprecedented size and scope, suggest that both climatic and non-climatic factors and conditions will influence farmers' adaptive intentions. Indeed, farmer decision making in the context of climate change adaptation will be based on a diverse array of biophysical, political, economic, and cultural factors. This study highlights the opportunity to engage with farmers, who are confident in their ability to adapt and are generally willing to take steps to mitigate weather 
related risks on their farms, by clarifying and promoting the practices that will reduce climate related risks at both the field and landscape-scale. Climate change adaptation efforts in the agricultural sector will ultimately need to be linked to a broader set of policies and targeted efforts that build more capacity for purposeful adaptation designed to respond to long-term changes in the climate (Howden et al. 2007). Improved engagement will be critical in developing strategies to enhance the adaptive capacity of corn and soybean farmers in the US Corn Belt to respond to a changing climate.

Acknowledgments The team members involved in this research are part of a regional collaborative project supported by the US Department of Agriculture-National Institute of Food and Agriculture, Award No. 2011-68002-30190, Cropping Systems Coordinated Agricultural Project: Climate Change, Mitigation, and Adaptation in Corn-based Cropping Systems. Project Web site: www.sustaina blecorn.org.

Open Access This article is distributed under the terms of the Creative Commons Attribution 4.0 International License (http://creative commons.org/licenses/by/4.0/), which permits unrestricted use, distribution, and reproduction in any medium, provided you give appropriate credit to the original author(s) and the source, provide a link to the Creative Commons license, and indicate if changes were made.

\section{Appendix}

A confirmatory factor analysis was conducted to develop productivist and stewardship identity constructs. The survey question was measured on a 5-point Likert scale $(1=$ Strongly Disagree, $5=$ Strongly Agree). The survey question and the standardized factor loadings are provided. A partial information estimator was used to develop the factor scores due to the ordinal nature of the response variables.

\begin{tabular}{lll}
\hline Factors & Question/statement & $\begin{array}{l}\text { Standardized } \\
\text { factor (Lamda) } \\
\text { loading }\end{array}$ \\
\hline $\begin{array}{l}\text { Productivist } \\
\text { identity }\end{array}$ & $\begin{array}{c}\text { A good farmer is one who has the } \\
\text { highest yields per hectare } \\
\text { A good farmer is one who gets } \\
\text { their crops planted first }\end{array}$ & 0.584 \\
& $\begin{array}{l}\text { A good farmer is one who has the } \\
\text { highest profit per hectare }\end{array}$ & 0.605 \\
& $\begin{array}{l}\text { A good farmer is one who has the } \\
\text { most up-to-date equipment }\end{array}$ & 0.677 \\
& $\begin{array}{l}\text { A good farmer is one who uses } \\
\text { the latest seed and chemical } \\
\text { technology }\end{array}$ & 0.679 \\
$\begin{array}{l}\text { A good farmer is one who } \\
\text { maximizes government } \\
\text { payments }\end{array}$ & 0.537 \\
\hline
\end{tabular}

\begin{tabular}{|c|c|c|}
\hline Factors & Question/statement & $\begin{array}{l}\text { Standardized } \\
\text { factor (Lamda) } \\
\text { loading }\end{array}$ \\
\hline \multirow[t]{9}{*}{$\begin{array}{l}\text { Stewardship } \\
\text { identity }\end{array}$} & $\begin{array}{l}\text { A good farmer is one who } \\
\text { considers the health of streams } \\
\text { that run through or along their } \\
\text { land to be their responsibility }\end{array}$ & 0.700 \\
\hline & $\begin{array}{l}\text { A good farmer is one who } \\
\text { minimizes erosion }\end{array}$ & 0.743 \\
\hline & $\begin{array}{l}\text { A good farmer is one who } \\
\text { minimizes nutrient runoff into } \\
\text { waterways }\end{array}$ & 0.759 \\
\hline & $\begin{array}{l}\text { A good farmer is one who thinks } \\
\text { beyond their own farm to the } \\
\text { social and ecological health of } \\
\text { their watershed }\end{array}$ & 0.771 \\
\hline & $\begin{array}{l}\text { A good farmer is one who } \\
\text { maintains or increases soil } \\
\text { organic matter }\end{array}$ & 0.759 \\
\hline & $\begin{array}{l}\text { A good farmer is one who } \\
\text { minimizes the use of pesticides }\end{array}$ & 0.583 \\
\hline & $\begin{array}{l}\text { A good farmer is one who } \\
\text { manages for both profitability } \\
\text { and minimization of } \\
\text { environmental impact }\end{array}$ & 0.758 \\
\hline & $\begin{array}{l}\text { A good farmer is one who scouts } \\
\text { before spraying for insects/ } \\
\text { weeds/disease }\end{array}$ & 0.660 \\
\hline & $\begin{array}{l}\text { A good farmer is one who puts } \\
\text { long-term conservation of farm } \\
\text { resources before short-term } \\
\text { profits }\end{array}$ & 0.672 \\
\hline
\end{tabular}

Fit statistics for confirmatory factor model with two latent constructs (Productivist Identity and Conservationist Identity): Chi-square fit index (0.380, d.f. $89, p$ value $>0.995$ ); RMSR value 0.0523 ; AGFI value 0.963 ). All indicate good fit, including no standardized residuals over 1.96

\section{References}

Adger, W.N., N.W. Arnell, and E.L. Tompkins. 2005. Successful adaptation to climate change across scales. Global Environmental Change 15: 77-86.

Ajzen, I. 1991. The theory of planned behavior. Organizational Behavior and Human Decision Processes 50: 179-211.

Arbuckle Jr., J.G. 2013. Farmer support for extending conservation compliance beyond soil erosion: Evidence from Iowa. Journal of Soil and Water Conservation 68(2): 99-109.

Arbuckle Jr., J.G., L.S. Prokopy, T. Haigh, J. Hobbs, T. Knoot, C. Knutson, A. Loy, A.S. Mase, J. McGuire, L.W. Morton, J. Tyndall, and M. Widhalm. 2013a. Climate change beliefs, concerns, and attitudes toward adaptation and mitigation among farmers in the Midwestern United States. Climatic Change 117: 943-950.

Arbuckle Jr., J.G., L.W. Morton, and J. Hobbs. 2013b. Farmer beliefs and concerns about climate change and attitudes toward adaptation and mitigation: Evidence from Iowa. Climatic Change 118: 551-563.

Arbuckle Jr., J.G., L.W. Morton, and J. Hobbs. 2013c. Understanding farmer perspectives on climate change adaptation and 
mitigation: The roles of trust in sources of climate information, climate change beliefs, and perceived risk. Environment and Behavior. doi:10.1177/0013916513503832.

Arbuckle Jr., J.G., J. Hobbs, A. Loy, L.W. Morton, L.S. Prokopy, and J. Tyndall. 2014. Understanding Corn Belt farmer perspectives on climate change to inform engagement strategies for adaptation and mitigation. Journal of Soil and Water Conservation 69(6): 505-516.

Arbuckle Jr., J., and G. Roesch-McNally. 2015. Cover crop adoption in Iowa: The role of perceived practice characteristics. Journal of Soil and Water Conservation 70(6): 418-429.

Arritt, R. 2016. Climate change in the Corn Belt. CSCAP-0193-2016. Ames, IA: Cropping Systems Coordinated Agricultural Project (CAP): Climate Change, Mitigation, and Adaptation in Cornbased Cropping Systems.

Atwell, R.C., L.A. Schulte, and L.M. Westphal. 2009. Landscape, community, countryside: Linking biophysical and social scales in US Corn Belt agricultural landscapes. Landscape Ecology 24: 791-806.

Barnett, J., and S. O'Neill. 2010. Maladaptation. Global Environmental Change 20: 211-213.

Baumgart-Getz, A., L.S. Prokopy, and K. Floress. 2012. Why farmers adopt best management practice in the US: A meta-analysis of the adoption literature. Journal of Environmental Management 96: $17-25$.

Blesh, J., and S.A. Wolf. 2014. Transitions to agroecological farming systems in the Mississippi River Basin: Toward an integrated socioecological analysis. Agriculture and Human Values 31: 621-635.

Brody, S.D., S. Zahran, A. Vedlitz, and H. Grover. 2008. Examining the relationship between physical vulnerability and public perceptions of global climate change in the United States. Environment and Behavior 40(1): 72-95.

Broussard, W.P., and R.E. Turner. 2009. A century of changing landuse and water-quality relationships in the continental US. Frontiers in Ecology and Environment 7(6): 302-307.

Broussard, W.P., R.E. Turner, and J.V. Westra. 2012. Do federal farm policies influence surface water quality? Agriculture, Ecosystems \& Environment 158: 103-109.

Burton, R.J.F. 2004. Seeing through the "good farmer's" eyes: Towards developing an understanding of the social symbolic value of productivist behavior. Sociologia Ruralis 44: 195-216.

Carolan, M.S. 2006. Social change and the adoption and adaptation of knowledge claims: Whose truth do you trust in regard to sustainable agriculture? Agriculture and Human Values 23: 325-339.

Chhetri, N.B., W.E. Easterling, A. Terando, and L. Mearns. 2014. Modeling path dependency in agricultural adaptation to climate variability and change. Annals of the Association of American Geographers 100(4): 894-907.

Constantin, J., B. Mary, F. Laurent, G. Aubrion, A. Fontaine, P. Kerveillant, and N. Beaudoin. 2010. Effects of catch crops, no till and reduced nitrogen fertilization on nitrogen leaching and balance in three long-term experiments. Agriculture, Ecosystems \& Environment 135(4): 268-278.

Coughenour, C.M. 2003. Innovating conservation agriculture: The case of no-till cropping. Rural Sociology 68(2): 278-305.

Coughenour, C.M., and S. Chamala. 2000. Conservation tillage and cropping innovation: Constructing the new culture of agriculture. Ames, IA: Iowa State University Press.

Cutler, M.J. 2015. Seeing and believing: the emergent nature of extreme weather perceptions. Environmental Sociology 1(4): 293-303.

Donner, S.D., and C.J. Kucharik. 2008. Corn-based ethanol production compromises goal of reducing nitrogen export by the Mississippi River. PNAS 105(11): 4513-4518.

Fishbein, M., and I. Ajzen. 2010. Predicting and changing behavior: The reasoned action approach. New York: Taylor and Francis.
Fuglie, K.O., J.M. MacDonald, and E. Ball. 2007. Productivity growth in US agriculture. Economic Research Service USDA.

Goolsby, D.A., W.A. Battaglin, G.B. Lawrence, R.S. Artz, B.T. Aulenbach, R.P. Hooper, D.R. Keeney, and G.J. Stensland. 1999. Flux and sources of nutrients in the Mississippi-Atchafalaya River Basin: Topic 3 report for the Integrated Assessment of Hypoxia in the Gulf of Mexico. Decision Analysis Series. NOAA Coastal Ocean Program.

Hatfield, J., G. Takle, R. Grotjahn, P. Holden, R.C. Izaurralde, T. Mader, and E. Marshall. 2014. Climate change impacts in the United States: The third national climate assessment. US Congress: 150-174.

Hoorman, J.J. 2009. Using cover crops to improve soil and water quality. The Ohio State University Extension Fact Sheet for Agriculture and Natural Resources.

Howden, S.M., F. Soussana, F.N. Tubiello, N. Chhetri, M. Dunlop, and H. Meinke. 2007. Adapting agriculture to climate change. The National Academy of Sciences of the USA 104(50): 19691-19696.

Hyland, J.J., D.L. Jones, K.A. Parkhill, A.P. Barnes, and A.P. Williams. 2015. Farmers' perceptions of climate change: identifying types. Agriculture and Human Values 33(2): 323-339.

ISUEO (Iowa State University Extension and Outreach). 2014. Iowa Nutrient Reduction Strategy: a science and technology-based framework to assess and reduce nutrients to Iowa waters and the Gulf of Mexico. Ames, IA.

IPCC (Intergovernmental Panel on Climate Change). 2014. Summary for policymakers. In Climate change 2014: Impacts, adaptation, and vulnerability. Part A: Global and sectoral aspects. Contribution of Working Group II to the Fifth Assessment Report of the Intergovernmental Panel on Climate Change, ed. C.B. Field, V.R. Barros, D.J. Dokken, K. J. Mach, M. D. Mastrandrea, T. E. Bilir, M. Chatterjee, K.L. Ebi, Y.O. Estrada, R.C. Genova, B. Girma, E.S. Kissel, A.N. Levy, S. MacCracken, P.R. Mastrandrea, and L.L. White, pp. 1-32.

Jordan, N., and K.D. Warner. 2010. Enhancing the multifunctionality of US agriculture. Bioscience 60(1): 60-66.

Klöckner, C.A. 2013. A comprehensive model of the psychology of environmental behavior: A meta-analysis. Global Environmental Change 23(5): 1028-1038.

Knowler, D., and B. Bradshaw. 2007. Farmers' adoption of conservation agriculture: A review and synthesis of recent research. Food Policy 32: 25-48.

Lin, B.B. 2011. Resilience in agriculture through crop diversification: Adaptive management for environmental change. BioScience 61(3): 183-193.

Loy, A., J. Hobbs, J.G. Arbuckle Jr., L.W. Morton, L.S. Prokopy, T. Haigh, T. Knoot, C. Knutson, A.S. Mase, J. McGuire, J. Tyndall, and M. Widhalm. 2013. Farmer perspectives on agriculture and weather variability in the Corn Belt: A statistical atlas. CSCAP (Cropping Systems Coordinated Agricultural Project): Climate Change, Mitigation, and Adaptation in Corn-based Cropping Systems Coordinated Agricultural Project 0153-2013. Ames, IA.

McGuire, J., L.W. Morton, and A.D. Cast. 2013. Reconstructing the good farmer identity: Shifts in farmer identities and farm management practices to improve water quality. Agriculture and Human Values 30: 57-69.

Melillo, J.M., T.C. Richmond, and G.W. Yohe. 2014. Highlights of climate change impacts in the United States: The third national climate assessment. US Congress.

Morton, L.W., J. Hobbs, J.G. Arbuckle, and A. Loy. 2015. Upper Midwest climate variations: Farmer responses to excess water risks. Journal of Environmental Quality 44: 810-822.

Morton, L.W., L.S. Prokopy, J.G. Arbuckle, Jr., C. Ingels, M. Thelen, R. Bellm, D. Bowman, L. Edwards, C. Ellis, R. Higgins, T. Higgins, D. Hudgins, R. Hoorman, J. Neufelder, B. Overstreet, A. Peltier, H. Schmitz, J. Voit, C. Wegehaupt, S. Wohnoutka, R. Wolkowski, L. Abendroth, J. Angel, T. Haigh, C. Hart, J. Klink, 
C. Knutson, R. Power, D. Todey, and M. Widhalm. 2016. Climate change and agricultural extension: building capacity for Land Grant Extension Services to address the agricultural impacts of climate change and the adaptive management needs of agricultural stakeholders. Technical report series: Findings and recommendations of the Climate and Corn-based Cropping Systems Coordinated Agricultural Project 0192-2016. Ames, IA.

Moser, S.C., and J.A. Ekstrom. 2010. A framework to diagnose barriers to climate change adaptation. PNAS 107(51): 22026-22031.

NASS (National Agricultural Statistics Service). 2009. Agricultural census. US Department of Agriculture National Agricultural Statistics Service: 2007 Census of Agriculture.

NASS (National Agricultural Statistics Service). 2014a. Farm economics: Record high agriculture sales: income and expenses both up. US Department of Agriculture National Agricultural Statistics Service: 2012 Census of Agriculture.

NASS (National Agricultural Statistics Service). 2014b. US Department of Agriculture National Agricultural Statistics Service Conservation: producers protect or improve millions of acres of agricultural land. 2012 Census of Agriculture.

Nelson, D.R., W.N. Adger, and K. Brown. 2007. Adaptation to environmental change: Contributions of a resilience framework. Annual Review of Environment and Resources 32: 395-419.

Nelson, K.C., R.F. Brummel, N. Jordan, and S. Manson. 2014. Social networks in complex human and natural systems: The case of rotational grazing, weak ties, and eastern US dairy landscapes. Agriculture and Human Values 31: 245-259.

O'Connor, R.E., R.J. Bord, and A. Fisher. 1999. Risk perceptions, general environmental beliefs, and willingness to address climate change. Risk Analysis 19: 461-471.

OECD (Organization for Economic Co-operation and Development). 2012. Farmer behavior, agricultural management, and climate change. Paris, France.

Oquist, K.A., J.S. Strock, and D.J. Mulla. 2007. Influence of alternative and conventional farming practices on subsurface drainage and water quality. Journal of Environmental Quality 36: 1194-1204.

Pannell, D.J., G.R. Marshall, N. Barr, A. Curtis, F. Vanclay, and R. Wilkinson. 2006. Understanding and promoting adoption of conservation practices by rural landholders. Australian Journal of Experimental Agriculture 46: 1407-1424.

Prokopy, L.S., K. Floress, D. Klotthor-Weinkauf, and A. BaumgartGetz. 2008. Determinants of agricultural best management practice adoption: Evidence from the literature. Journal of Soil and Water Conservation 63(5): 300-311.

Reilly, J., F. Tubiello, B. McCarl, D. Abler, R. Darwin, K. Fuglie, S. Hollinger, C. Izaurralde, S. Jagtap, J. Jones, L. Mearns, D. Ojima, E. Paul, K. Paustian, S. Riha, N. Rosenberg, and C. Rosenzweig. 2003. US agriculture and climate change: New results. Climatic Change 57: 43-69.

Reimer, A.P., K. Weinkauf, and L.S. Prokopy. 2012a. The influence of perceptions of practice characteristics: An examination of agricultural best management practice adoption in two Indiana watersheds. Journal of Rural Studies 28: 118-128.

Reimer, A.P., A.W. Thompson, and L.S. Prokopy. 2012b. The multidimensional nature of environmental attitudes among farmers in Indiana: Implications for conservation adoption. Agriculture and Human Values 29: 29-40.

Rejesus, R.M. 2013. US agricultural producer perceptions of climate change. Journal of Agricultural and Applied Economics 45(4): 701-718.

Rogers, E.M. 1995. Diffusion of innovations, 4th ed. New York, NY: The Free Press.

Saltiel, J., J.W. Bauder, and S. Palakovich. 1994. Adoption of sustainable agriculture practices: Diffusion, farm structure, and profitability. Rural Sociology 59(2): 333-349.
Schneider, F., T. Ledermann, P. Fry, and S. Rist. 2010. Soil conservation in Swiss agriculture: Approaching abstract and symbolic meanings in farmers' life-worlds. Land Use Policy 27: 332-339.

Schnepf, M., and C. Cox (eds.). 2006. Environmental benefits of conservation on cropland: The status of our knowledge. Ankeny, IA: Soil and Water Conservation Society.

Schwartz, S.H., and J.A. Howard. 1981. A normative decisionmaking model of altruism. In Altruism and helping behavior, ed. J. P. Rushton and R. M. Sorrentino, 89-211. Hillsdale, NJ: Lawerence Erlbaum.

Singer, J.W., S.M. Nusser, and C.J. Alf. 2007. Are cover crops being used in the US Corn Belt? Journal of Soil and Water Conservation 62(5): 353-358.

Smit, B., and M.W. Skinner. 2002. Adaptations options in agriculture to climate change: A typology. Mitigation and Adaptation Strategies for Global Change 7: 85-114.

Smit, B., I. Burton, J. Richard, T. Klein, and J. Wandel. 2000. An anatomy of adaptation to climate change and variability. Climate Change 45: 223-251.

Soule, M.J., A. Tegene, and K.D. Wiebe. 2000. Land tenure and the adoption of conservation practices. Agricultural and Applied Economics 82(4): 993-1005.

Sugg, Z. 2007. Assessing US farm drainage: Can GIS lead to better estimates of subsurface drainage extent?. Washington, DC: World Resources Institute.

USDA-FAS (United States Department of Agriculture-Foreign Agricultural Service). 2015. Production, supply, and distribution online database. Accessed 6 Mar 2016 (http://www.fas.usda.gov/ psdonlin/)

Wilson, R.S., G. Howard, and E.A. Burnett. 2014. Improving nutrient management practices in agriculture: The role of risk-based beliefs in understanding farmers' attitudes toward taking additional action. Water Resources Research 50(8): 6735-6746.

Zahran, S., S.D. Brody, H. Grover, and A. Vedlitz. 2006. Climate change vulnerability and policy support. Society and Natural Resources Journal 19(9): 771-789.

Gabrielle E. Roesch-McNally earned her Ph.D. in Sustainable Agriculture and Sociology from Iowa State University. Dr. RoeschMcNally studies farmer transitions to more multifunctional forms of agriculture, resilience and climate change adaptation strategies of farmers, conservation practice use and adoption, and food insecurity as they relate to the organization of our formal and informal food system.

J. Gordon Arbuckle is an Associate Professor of Sociology at Iowa State University. His research and extension efforts focus on improving the environmental and social performance of agricultural systems. His primary area of interest is drivers of farmer and agricultural stakeholder decision making and action related to soil and water quality and adaptation to climate change.

John Charles Tyndall is an Associate Professor in the Natural Resource Ecology and Management Department at Iowa State University. Dr. Tyndall's research weaves financial, economic, and social perspectives into multi-disciplinary work examining the economic and ecological capacity of various landscapes/watersheds to be managed for broader arrays of ecosystem services while maintaining high commodity production rates. 